\title{
Atorvastatin Calcium Inhibits PDGF- $\beta \beta$ - Induced Proliferation and Migration of VSMCs Through the G0/G1 Cell Cycle Arrest and Suppression of Activated PDGFRß-PI3K-Akt Signaling Cascade
}

\author{
Shuang Chen ${ }^{\mathrm{a}}$ Siyuan Dong ${ }^{\mathrm{b}}$ Zhao Lia Xiaofan Guo ${ }^{\mathrm{a}}$ Naijin Zhang ${ }^{\mathrm{a}}$ Bo Yuc,d \\ Yingxian Sun ${ }^{\mathrm{a}}$ \\ aDepartment of Cardiology, the First Affiliated Hospital of China Medical University, Shenyang, \\ ${ }^{b}$ Department of Thoracic Surgery, the First Affiliated Hospital of China Medical University, Shenyang, \\ 'Department of Cardiology, the 2nd Affiliated Hospital of Harbin Medical University, Heilongjiang, \\ dThe Key Laboratory of Myocardial Ischemia, Harbin Medical University, Ministry of Education, \\ Heilongjiang, P.R. China
}

\section{Key Words}

Vascular smooth muscle cells • PDGF- $\beta \beta$ • Atorvastatin calcium • Akt

\begin{abstract}
Background/Aims: Abnormal proliferation of vascular smooth muscle cells (VSMCs) is a hallmark of vascular lesions, such as atherosclerosis and restenosis. PDGF- $\beta \beta$, an isoform of PDGF (platelet-derived growth factor), has been demonstrated to induce proliferation and migration of VSMCs. Atorvastatin calcium, a selective inhibitor of 3-hydroxy-3-methylglutaryl coenzyme A (HMG-CoA) reductase, has favorable protective effects on VSMCs. This study examined the effects of atorvastatin calcium on the proliferation and migration of PDGF- $\beta \beta$ treated VSMCs, as well as its underlying mechanisms. Methods: MTT assays, Edu imaging, cell cycle analysis, wound healing assays, transwell migration assays, and western blot analysis were performed. Results: Atorvastatin calcium significantly inhibited cell proliferation, DNA synthesis and cell migration of PDGF- $\beta \beta$-treated VSMCs. We demonstrated that atorvastatin calcium induced cell cycle arrest in the G0/G1 phase in response to PDGF- $\beta \beta$ stimulation and decreased the expression of G0/G1-specific regulatory proteins, including proliferating cell nuclear antigen (PCNA), CDK2, cyclin D1, cyclin E and CDK4 in PDGF- $\beta \beta$ treated VSMCs. Moreover, pretreatment with atorvastatin calcium inhibited the PDGF- $\beta \beta$ treated phosphorylation of PDGFR $\beta$ and Akt, whereas atorvastatin calcium did not affect the phosphorylation of PLC- $\gamma 1$ or (ERK) 1/2. Conclusion: Our data suggested that atorvastatin calcium inhibited abnormal proliferation and migration of VSMCs through G0/G1 cell cycle arrest and suppression of the PDGFR $\beta$-Akt signaling cascade.




\section{Cellular Physiology \begin{tabular}{ll|l} 
and Biochemistry $10.1159 / 000484648$ & $\begin{array}{l}\text { D } 2017 \text { The Author(s). Published by S. Karger AG, Basel } \\
\text { www.karger.com/cpb }\end{array}$ \\
\cline { 2 - 3 }
\end{tabular}}

\section{Introduction}

Abnormal proliferation and migration of vascular smooth muscle cells (VSMCs) play important roles in the development of vascular disorders, such as atherosclerosis, neointima formation and restenosis [1,2]. VSMCs are an important component of the media layer of mature blood vessels and have contractile characteristics to regulate blood vessel tone [3]. VSMCs normally exist in a non-proliferative quiescent state and express a series of contractile proteins, exhibiting differentiated and contractile phenotypes [4]. However, after vascular injury, including atherosclerosis, restenosis after angioplasty, stenting, or bypass surgery, VSMCs dedifferentiate to a synthetic phenotype and re-enter the cell cycle and undergo abnormal proliferation and migration [1,5-7]. The synthetic phenotype VSMCs lead to increased proliferation, migration and synthesis of extracellular matrix proteins, leading to intimal hyperplasia $[2,8,9]$.

Platelet-derived growth factor (PDGF), as one of the most potent mitogens and chemoattractants for VSMCs, is produced by activated macrophages, VSMCs, and endothelial cells, and PDGF plays an essential role in abnormal proliferation and migration of VSMCs [10]. The PDGF family includes PDGF-AA, PDGF- $\beta \beta$, PDGF-A $\beta$, PDGF-CC, and PDGF-DD. Among the isoforms of the PDGF family, PDGF- $\beta \beta$-treated proliferation of VSMCs has been well demonstrated $[11,12]$. The binding of PDGF- $\beta \beta$ to the PDGF receptor (PDGF-R) leads to the phosphorylation of PDGF-R $\beta$-chain (PDGF-R $\beta$ ) tyrosine residues and then activates many downstream signaling molecules, such as phosphatidylinositol 3-kinase (PI3K)/Akt, phospholipase C (PLC)- $\gamma 1$ and extracellular signal regulated kinase (ERK) 1/2 pathways [13-15]. It has been shown that Akt is a downstream target of PI3K and that both Akt and ERK1/2 signaling molecules play essential roles in cell proliferation, migration and other mammalian cellular processes [16-18]. Activation of these signaling pathways can lead to the progression and development of proliferative vascular diseases, including atherosclerosis and hypertension [18-20]. Therefore, modulation of the related signaling pathways may be a vital pharmacological point for the prevention of cardiovascular diseases.

Atorvastatin calcium, a 3-hydroxy-3-methylglutaryl coenzyme A (HMG-CoA) reductase inhibitor, has been widely used in clinical patients because of its lipid-reducing effect. Moreover, statins have also been reported to have a broad spectrum of biological activities, such as anti-oxidation, anti-inflammation and anti-thrombosis [21-24]. Although studies have demonstrated that statins can reduce intimal hyperplasia and slow atherosclerosis progression via inhibiting VSMCs proliferation and migration [25], the mechanisms behind the favorable effects of atorvastatin calcium on VSMCs are still not fully understood.

In this study, we examined the anti-proliferation and anti-migration effects of atorvastatin calcium on PDGF- $\beta \beta$-treated VSMCs. Furthermore, we evaluated the effects of atorvastatin calcium on PDGF- $\beta \beta$-treated cell cycle progression in VSMCs and on cell cycle regulatory proteins including cyclins and CDKs, as part of the early G0/G1 interphase transition. In addition, we also determined the effect of torvastatin calcium on the expression of migrationrelated proteins in PDGF- $\beta \beta$-treated VSMCs. Finally, we investigated atorvastatin calcium's influence on PDGF-R $\beta$, PI3K/Akt, PLC- $\gamma 1$, and ERK1/2 pathways in PDGF- $\beta \beta$-treated VSMCs.

\section{Materials and Methods}

\section{Ethics Statement}

All experimental protocols were approved by the Ethics Committee of China Medical University (Shenyang, China). All procedures were carried out in accordance with the ethical standards and the Guide for the Care and Use of Laboratory. Male Sprague-Dawley rats, 8 weeks, weighing 150-200 g were placed under general anesthesia with pentobarbital sodium $(50 \mathrm{mg} / \mathrm{kg})$ to harvest tissues for VSMC isolation as described previously [26], and all efforts were made to minimize suffering.

\section{KARGER}




\section{Cellular Physiology

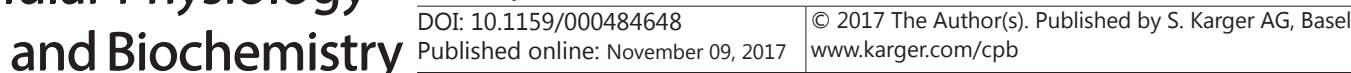 \\ Chen et al.: ATV Inhibits VSMCs Proliferation and Migration Through PDGFRß-PI3K-Akt}

\section{Isolation and culture of VSMCs}

The VSMCs were isolated from male Sprague-Dawley rats as described previously [26] and cultured in DMEM (Thermo Fisher, Shanghai, China) supplemented with $10 \%$ fetal bovine serum (FBS; Thermo Fisher, Shanghai, China) and $1 \%$ antibiotics at $37.0^{\circ} \mathrm{C}$ in a humidified $5 \% \mathrm{CO}_{2}$ incubator. VSMCs from passages 4-7 were used in this experiment. The VSMCs were cultured for $48 \mathrm{~h}$ and serum-starved for $24 \mathrm{~h}$ before each experiment.

\section{Cell proliferation assay and DNA Synthesis}

Cell proliferation and DNA synthesis were determined as previously described [26]. In brief, for direct cell counting, VSMCs were seeded into 12 -well culture plates at $4 \times 10^{4}$ cells $/ \mathrm{ml}$ and then cultured in DMEM containing $10 \% \mathrm{FBS}$ at $37.0^{\circ} \mathrm{C}$ until $70 \sim 80 \%$ cell confluence, and the cells were incubated with serum-free medium for $24 \mathrm{~h}$ and treated with various concentrations of atorvastatin calcium (dissolved in methanol) for $30 \mathrm{~min}$ in fresh medium and then stimulated by PDGF- $\beta \beta(20 \mathrm{ng} / \mathrm{ml})$ for $24 \mathrm{~h}$. The cells were trypsinized and counted using a hemocytometer under microscopy.

For the MTT assay, cells were seeded in 96-well culture plates (5000/well) and incubated with 0.5 $\mathrm{mg} / \mathrm{mL}$ MTT in the last $4 \mathrm{~h}$ of the culture period at $37^{\circ} \mathrm{C}$. The reaction was terminated by incubating the cells with DMSO for $10 \mathrm{~min}$. An automatic microplate reader microplate reader (Bio-Rad, Hercules, CA, USA) was used to determine the absorbance at $570 \mathrm{~nm}$.

DNA synthesis was performed by a 5 -ethynyl-2'-deoxyuridine (Edu) incorporation assay (Click-iT ${ }^{\circledR}$ EdU Imaging Kits, Invitrogen, USA) according to the manufacturer's instructions. Briefly, cells were incubated with EdU-labeling solution for $2 \mathrm{~h}$ at $37^{\circ} \mathrm{C}$, and then the cells were fixed cells with $4 \%$ cold formaldehyde for $30 \mathrm{~min}$ at room temperature. After permeabilization with $1 \%$ Triton X-100, the cells were reacted with Click-iT ${ }^{\circledR}$ reaction cocktails (Invitrogen) for $30 \mathrm{~min}$. Subsequently, the DNA contents of the cells were stained with Hoechst 33342 for $30 \mathrm{~min}$. Finally, EdU-labeled cells were counted using fluorescence microscopy (CKX41-F32FL, Olympus) and normalized to the total number of Hoechst-stained cells.

\section{Cell cycle progression analysis}

VSMCs were seeded into 6-well culture plates at $1 \times 10^{5}$ cells $/ \mathrm{mL}$ and then cultured in DMEM containing $10 \% \mathrm{FBS}$ at $37^{\circ} \mathrm{C}$ for $24 \mathrm{~h}$ until $70 \sim 80 \%$ confluence. The medium was then replaced with serum-free media for $24 \mathrm{~h}$. Cells were stimulated with $20 \mathrm{ng} / \mathrm{mL}$ PDGF- $\beta \beta$ with or without atorvastatin calcium for $24 \mathrm{~h}$, trypsinized, and then centrifuged at $1500 \times \mathrm{g}$ for $10 \mathrm{~min}$. The resulting pellets were suspended in $1 \mathrm{~mL}$ of $1 \times \mathrm{PBS}$, washed twice, and re-centrifuged. The pellets were suspended in $70 \%$ ethanol and fixed overnight at $4^{\circ} \mathrm{C}$. The fixed VSMCs were briefly vortexed and centrifuged at $15,000 \times \mathrm{g}$ for $5 \mathrm{~min}$. The ethanol was discarded and the pellets were stained with $0.4 \mathrm{~mL}$ of propidium iodide (PI) solution $(50 \mu \mathrm{g} / \mathrm{mL}$ PI in buffer containing $100 \mu \mathrm{g} / \mathrm{mL}$ of RNase A). Samples were incubated for $1 \mathrm{~h}$ at room temperature before analysis by flow cytometry. The PI-DNA complex in each cell nucleus was measured using a FACScan instrument (Becton Dickinson, IN, United States). The proportions of cells in G0/G1, S and G2/M phases were determined using the computer program ModFitLT (Verity Software House, Topsham, ME, USA).

\section{Wound healing assay}

VSMCs were seeded into 6-well culture plates until 70 80\% confluence. The VSMCs were cultured with serum-free media for $24 \mathrm{~h}$. Subsequently, a scratch was gently made using a sterile pipette tip, and the cells were then stimulated with $20 \mathrm{ng} / \mathrm{mL}$ PDGF- $\beta \beta$ with or without atorvastatin calcium. The wounds were visualized and photographed at $0 \mathrm{~h}$ (immediately) and $24 \mathrm{~h}$ after the scratch.

\section{Modified boyden chamber assay}

Cell migration was also performed using a modified Boyden chamber model (Transwell, $8.0 \mathrm{~m}$ pore size, Corning, NY) as previously described. Cells suspensions were seeded in the upper chambers. PDGF- $\beta \beta$ with or without ATV was added to the bottom chamber as the chemoattractant. The cells were allowed to migrate through the membrane to the lower surface for $24 \mathrm{~h}$. Cells on the upper surface of the membrane that had not migrated were scraped off with cotton swabs, and cells that had migrated to the lower surface were fixed by $3.7 \%$ paraformaldehyde, stained with DAPI, and counted. The migrated cell numbers were calculated as the number of migrated cells per 5 different random high-power fields. 


\section{Cellular Physiology

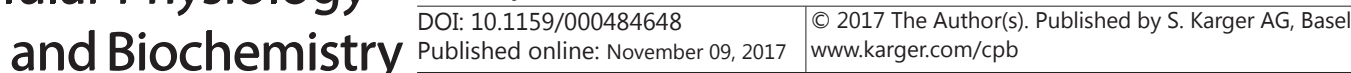 \\ Chen et al.: ATV Inhibits VSMCs Proliferation and Migration Through PDGFRß-PI3K-Akt}

Western blot analysis

The cell lysates were separated using sodium dodecyl sulfate-polyacrylamide gel electrophoresis (SDS-PAGE; 10-15\% acrylamide gels) and then transferred to nitrocellulose membranes (Millipore, MA, USA) using a standard SDS-PAGE gel electrophoresis procedure. Membranes were then blocked at room temperature in Tris-buffered saline containing 0.1\% Tween 20 (TBST) and 5\% skim milk powder for $1 \mathrm{~h}$. Membranes were incubated with primary antibodies for $4 \mathrm{~h}$, and horseradish peroxidase (HRP)-conjugated secondary antibodies were used for detection. Primary antibodies used in this study were the following: anti-PCNA, anti-CDK2, anti-CDK4, anti-cyclin D1, anti-cyclin E, anti-phospho-PDGF-R $\beta$, anti-PDGF-R $\beta$, antiphospho-Akt (Ser473), anti-Akt, anti-phospho-PLC- $\gamma 1$, anti-PLC- $\gamma 1$, anti-phospho-ERK1/2, anti-ERK1/2, and anti-GAPDH. Signal intensity was quantified using Image 1.47 software (NIH, USA).

\section{Zymography}

MMP-2 and MMP-9 activities in the medium were analyzed by non-reducing SDS-PAGE in 10\% gels containing $0.1 \%$ gelatin as previously described [27]. The zymograms were photographed and proteolysis was detected as a white zone in a blue background.

\section{Statistical analysis}

All variables were tested in three independent cultures for each experiment. Data are reported as the mean \pm standard deviation (SD) and were analyzed using one-way analysis of variance (ANOVA). All analyses were performed using SPSS 18.0 statistical software (SPSS, Inc, Chicago, IL, USA). P $<0.05$ was considered to indicate a statistically significant difference.

\section{Results}

Inhibitory effect of atorvastatin calcium on PDGF- $\beta \beta$-treated proliferation of VSMCs

We first examined the effect of atorvastatin calcium on PDGF- $\beta \beta$-treated proliferation of VSMCs by direct cell counting, MTT assay and EdU incorporation assay. Stimulation with PDGF- $\beta \beta(20 \mathrm{ng} / \mathrm{ml})$ for $24 \mathrm{~h}$ resulted in a significant increase in the number of VSMCs, which was decreased by atorvastatin calcium pretreatment in a concentration-dependent manner (Fig. 1A). In addition, atorvastatin calcium treatment in the absence of PDGF- $\beta \beta$ did not decrease the proliferation of VSMCs compared with the blank control ( $p>0.05)$. Similarly, the MTT assay showed the same inhibitory pattern on VSMC proliferation (Fig. 1B). Cell proliferation was further confirmed by $\left[{ }^{3} \mathrm{H}\right]$-thymidine DNA incorporation. As shown in Fig. $1 \mathrm{C}$ and D, PDGF- $\beta \beta$ treatment significantly increased the DNA synthesis of VSMCs up to 1.7fold compared with the untreated cells. DNA synthesis was inhibited by co-administration of PDGF- $\beta \beta$ and atorvastatin calcium $(1,5$ and $10 \mu \mathrm{M})$. These results indicated that atorvastatin calcium played an inhibitory effect on PDGF- $\beta \beta$-treated VSMCs proliferation.

\section{The effect of atorvastatin calcium on PDGF- $\beta \beta$-treated cell cycle progression}

We determined whether atorvastatin calcium may modulate the cell cycle progression of PDGF- $\beta \beta$-treated VSMCs using flow cytometry analysis. Serum deprivation of VSMCs for $24 \mathrm{~h}$ led to a $2.51 \%$ synchronization in the $\mathrm{S}$ phase of cell cycle progression. Compared with the control group, stimulation with $2 \mu \mathrm{M}$ atorvastatin calcium alone did not affect the cell cycle progression. PDGF- $\beta \beta$ increased the percentage of cells into the $S$ phase (from $2.51 \%$ to $28.88 \%$ ) with a concomitant decrease in cells in the G0/G1 phase. However, $2 \mu \mathrm{M}$ atorvastatin calcium in PDGF- $\beta \beta$-treated VSMCs significantly reduced the percentage of cells in the $\mathrm{S}$ phase to approximately $16.82 \%$, indicating that atorvastatin calcium may induce G0/ G1 phase arrest in VSMCs (Fig. 2).

The effect of atorvastatin calcium on cell cycle regulatory protein expression

Eukaryotic cell growth is governed by cell cycle progression, and a growth signal activates an interaction between CDKs and cyclins. To investigate the mechanism of cell cycle arrest by atorvastatin calcium, we next analyzed the effect of atorvastatin calcium on the expression of cell cycle regulatory proteins, which could be involved in the G0/G1 arrest 


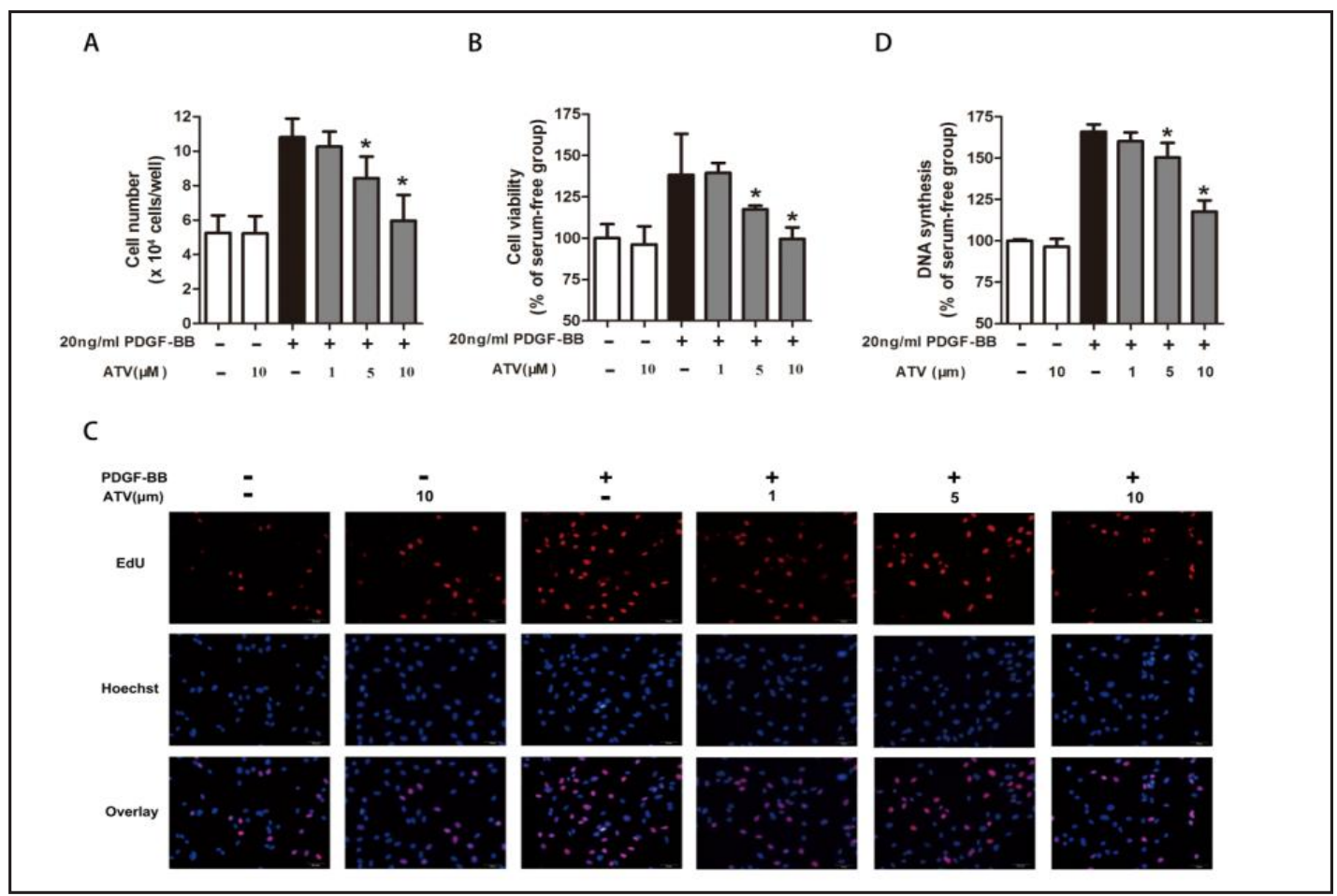

Fig. 1. Inhibitory effect of atorvastatin calcium on PDGF- $\beta \beta$-treated proliferation of VSMCs. After $24 \mathrm{~h}$ of starvation with serum-free DMEM, VSMCs were incubated with $20 \mathrm{ng} / \mathrm{mL}$ PDGF- $\beta \beta$ and increasing concentrations $(1,5,10 \mu \mathrm{M})$ of atorvastatin calcium (ATV) for 24h. (A) VSMCs were trypsinized, and their numbers were determined using hemocytometer. (B) VSMCs viability was evaluated by MTT assay. (C) EdU fluorescence staining to detect the newly synthesized DNA. (D) The percentage of EdU (+) cells was calculated by ImageJ 1.47 software. $* P<0.05$ compared with $20 \mathrm{ng} / \mathrm{mL}$ PDGF- $\beta \beta$-treated controls.

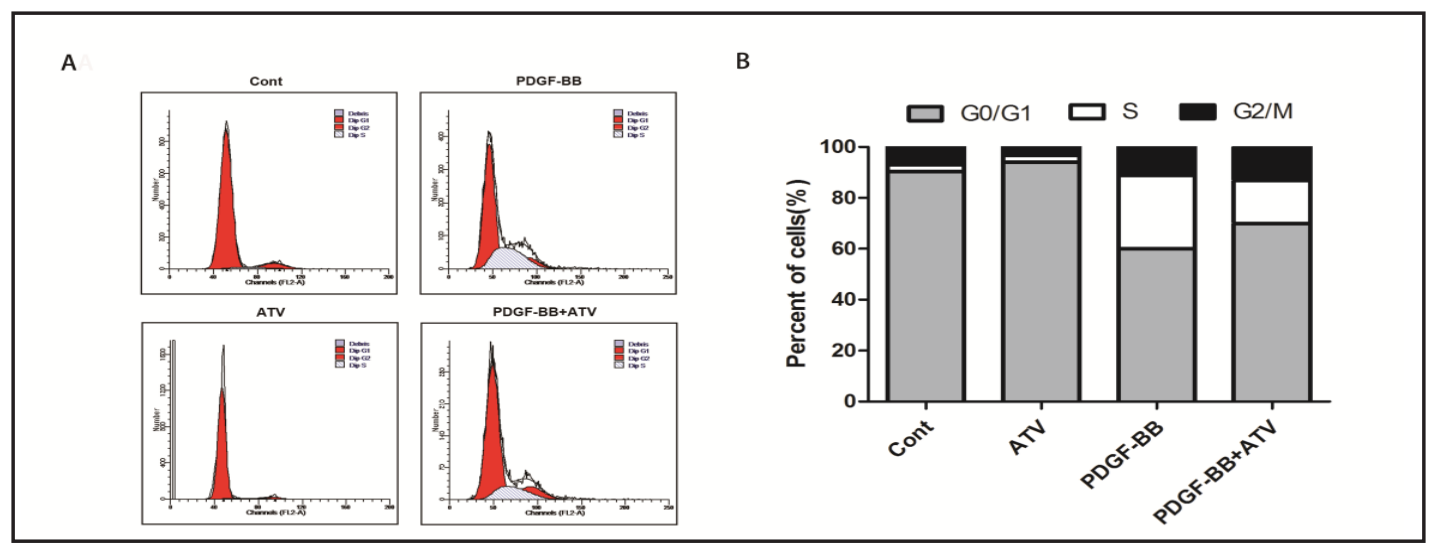

Fig. 2. The effect of atorvastatin calcium on PDGF- $\beta \beta$-treated cell cycle progression. After $24 \mathrm{~h}$ of starvation with serum-free DMEM, VSMCs were incubated with $20 \mathrm{ng} / \mathrm{mL}$ PDGF- $\beta \beta$ with or without ATV for 24h. (A) Individual nuclear DNA content was reflected by the fluorescence intensity of incorporated propidium iodide. Each item is derived from representative experiments, where data from at least 10,000 events were obtained. (B) The percentages of cell population at each stage are expressed as Mean values from three independent experiments.

(Fig. 3). PDGF- $\beta \beta$ markedly increased in the cellular levels of PCNA, cyclin D1, CDK4, cyclin $\mathrm{E}$ and CDK2 in VSMCs (Fig. 3). In contrast, $2 \mu \mathrm{M}$ atorvastatin calcium treatment attenuated the expression of PCNA, cyclin D1, CDK4, cyclin E and CDK2 in PDGF- $\beta \beta$-stimulated VSMCs. 

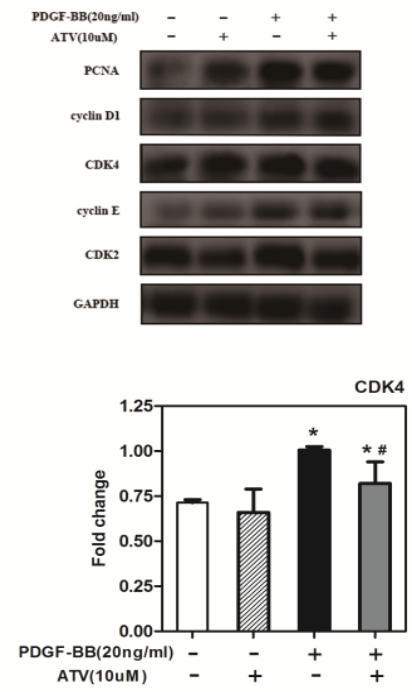
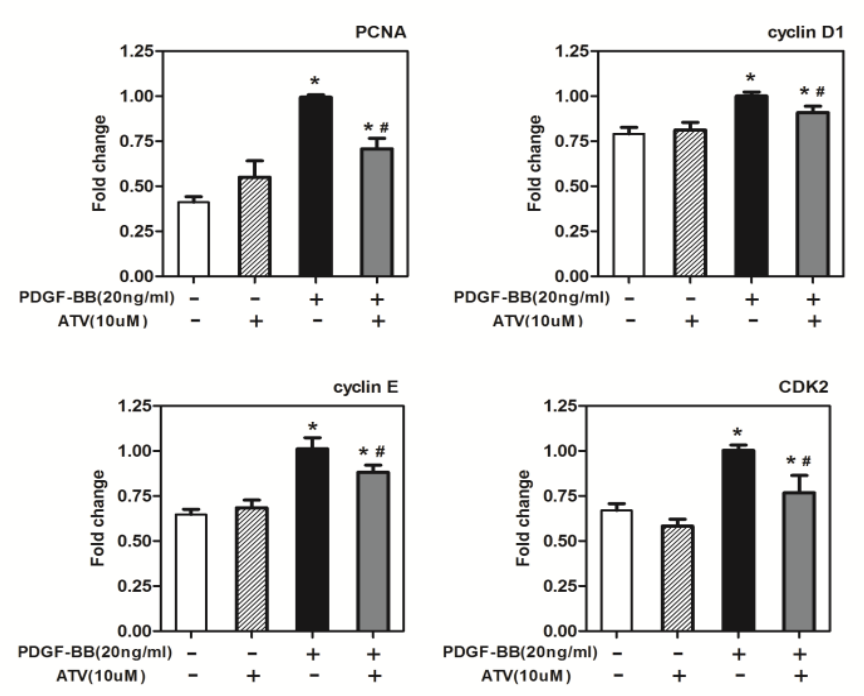

Fig. 3. The effect of atorvastatin calcium on cell cycle regulatory protein expression. After $24 \mathrm{~h}$ of starvation with serum-free DMEM, VSMCs were incubated with $20 \mathrm{ng} / \mathrm{mL}$ PDGF- $\beta \beta$ with or without ATV for $24 \mathrm{~h}$. The protein expression levels of PCNA, cyclin D1, CDK4, cyclin E and CDK2 were determined by western blotting. GAPDH, glyceraldehyde 3-phosphate dehydrogenase. The band intensity was quantified using Image 1.47 software and relative expression averaged across the three experiments. Probability values are indicated above bars: $* P<0.05$ compared with nonstimulated controls; $\# P<0.05$ compared with $20 \mathrm{ng} / \mathrm{mL}$ PDGF-BBinduced controls.

These results suggested that atorvastatin calcium inhibited the cell cycle progression at the $S$ phase via G0/G1 arrest.

\section{Inhibitory effects of atorvastatin calcium on PDGF- $\beta \beta$-treated VSMCs migration}

To evaluate the effect of atorvastatin calcium on the PDGF- $\beta \beta$-treated migration of VSMCs, we performed two different migration assays. As shown in Fig. 4A, a wound-healing assay was performed. Treatment with PDGF- $\beta \beta$ for $24 \mathrm{~h}$ narrowed the wound distance and increased migration of VSMCs by about 5 -fold after $24 \mathrm{~h}$ of treatment. Compared with PDGF- $\beta \beta$ treatment alone, atorvastatin calcium pretreatment attenuated PDGF- $\beta \beta$-treated migration of VSMCs to approximately $70 \%$. Next, we examined the effect of atorvastatin calcium on PDGF- $\beta \beta$-treated VSMCs migration by Transwell assay. Like the results of woundhealing assay, we found the atorvastatin calcium could suppress the PDGF- $\beta \beta$-treated VSMCs migration (Fig. 4B).

\section{Atorvastatin calcium inhibits migration-related protein expression and VSMCs migration} induced by PDGF- $\beta \beta$

Next, we studied the underlying mechanisms of atorvastatin calcium on PDGF- $\beta \beta$ treated VSMC migration through Western blot analysis (Fig. 5). It is reported that matrix metalloproteinases (MMPs) are involved in extracellular matrix (ECM) breakdown and are related to the development of atherosclerosis [28]. Thus, we examined the effect of atorvastatin calcium on several migration-regulated proteins and adhesion molecules, such as intercellular adhesion molecule 1 (ICAM-1), vascular cell adhesion molecule 1 (VCAM-1), MMP-2, and MMP-9. Our results revealed that atorvastatin calcium pretreatment inhibited the upregulation of ICAM-1, VCAM- 1 , MMP-2, and MMP- 9 induced by PDGF- $\beta \beta$. Furthermore, the zymography assay showed that atorvastatin calcium decreased MMP-2 and MMP-9 activities induced by PDGF- $\beta \beta$ in VSMCs. These findings suggested that atorvastatin calcium pretreatment reduced PDGF- $\beta \beta$-treated VSMCs migration by suppressing the expression of migration-related proteins. 

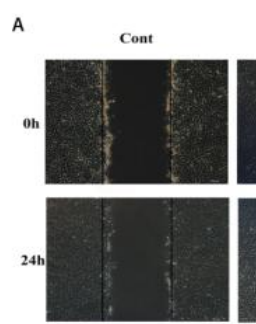

B

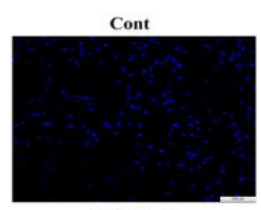

PDGF-BB

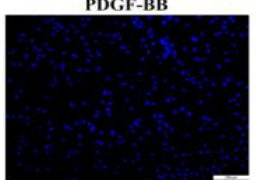

ATV
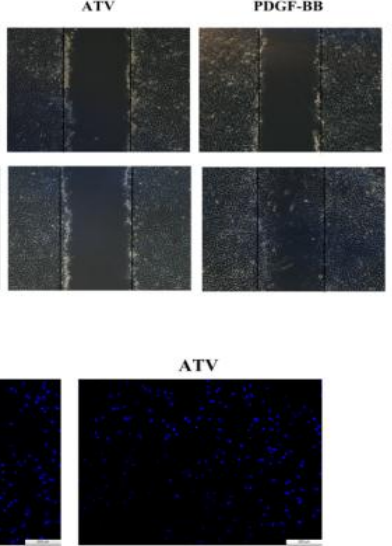

PDGF-BB+ATV

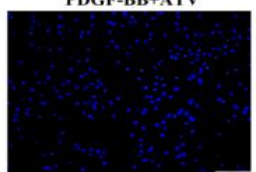

PDGF-BB+ATV
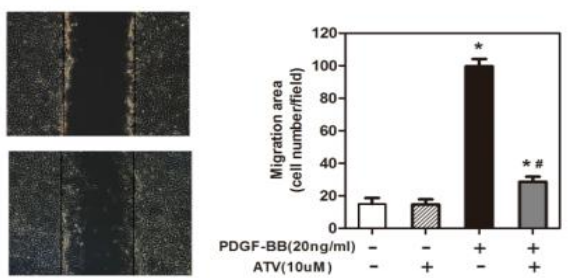

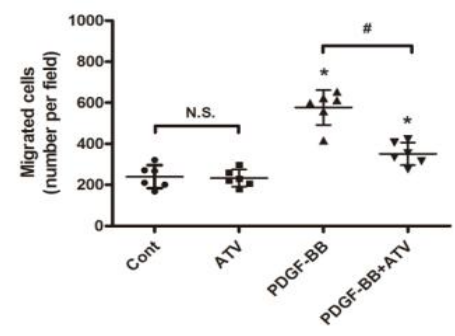

Fig. 4. Inhibitory effects of atorvastatin calcium on PDGF- $\beta \beta$-treated VSMCs migration. (A) Wound-healing assay showed that ATV inhibited PDGF- $\beta \beta$-treated VSMCs migration, 100×. (B) Transwell assay was used for the evaluation of the migration of VSMCs. Magnification, 100×. Cell migration was determined by counting the cells that migrated through the pores. The results were presented as the means \pm SEM from 3 different experiments. $* P<0.05$ compared with nonstimulated controls; $\# P<0.05$ compared with 20ng/mL PDGF$\beta \beta$-treated controls.

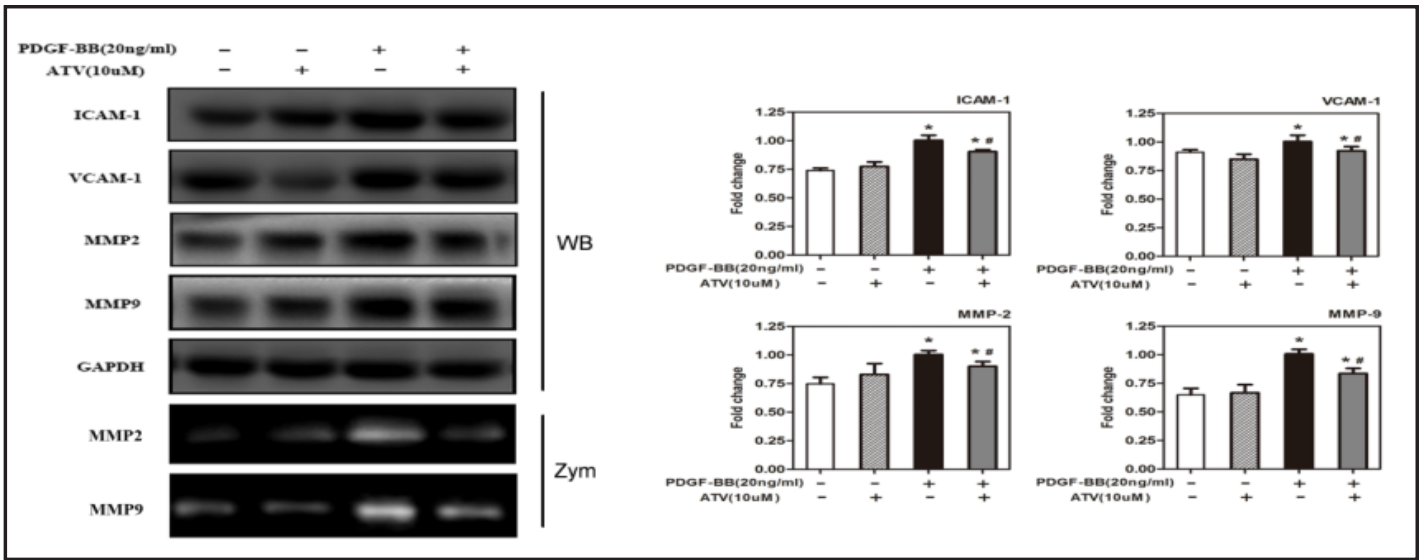

Fig. 5. Atorvastatin calcium inhibits migration-related proteins expression and VSMCs migration induced by PDGF- $\beta \beta$. After $24 \mathrm{~h}$ of starvation with serum-free DMEM, VSMCs were incubated with 20ng/mL PDGF$\beta \beta$ with or without ATV for $24 \mathrm{~h}$. The protein expression levels of ICAM-1, VCAM-1, MMP-2, and MMP-9 were determined by western blotting, and the enzymatic activities of MMP- 2 and MMP-9 in the conditioned medium were measured by gelatin zymography assay. The band intensity was quantified using ImageJ 1.47 software and relative expression averaged across the three experiments. $* P<0.05$ compared with nonstimulated controls; $\# P<0.05$ compared with $20 \mathrm{ng} / \mathrm{mL}$ PDGF- $\beta \beta$-treated controls. WB, Western blot; Zym, Zymograph.

Atorvastatin calcium inhibits the activation of PDGF-Rß signaling and Akt signaling pathways

PDGF- $\beta \beta$ binding to the PDGF receptor leads to the activation of several intracellular signaling cascades [29-31]. We next determined whether atorvastatin calcium affects 
A
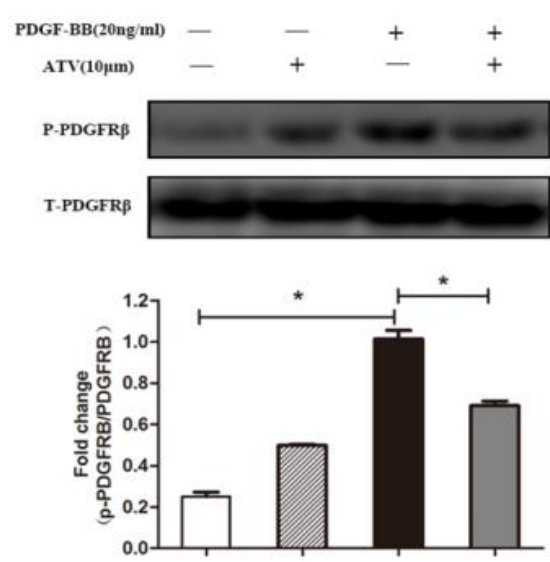

C
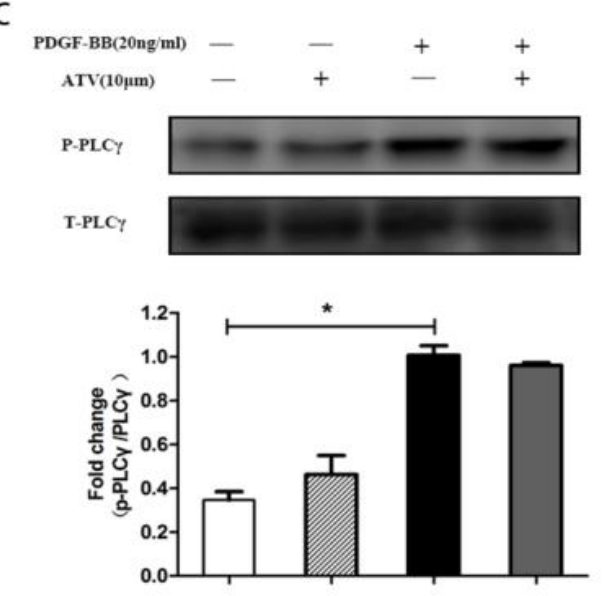

B
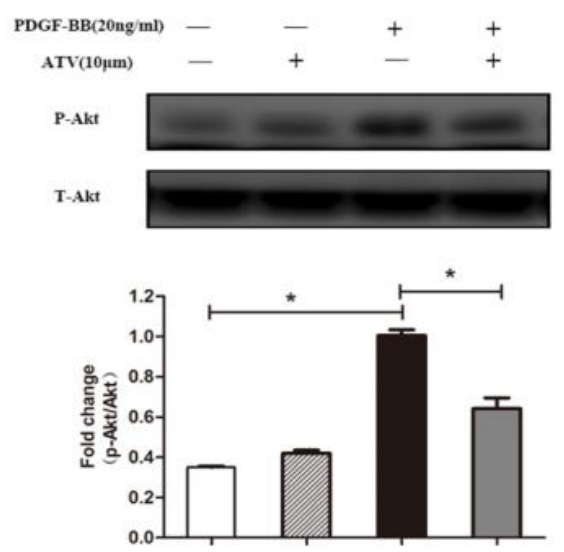

D
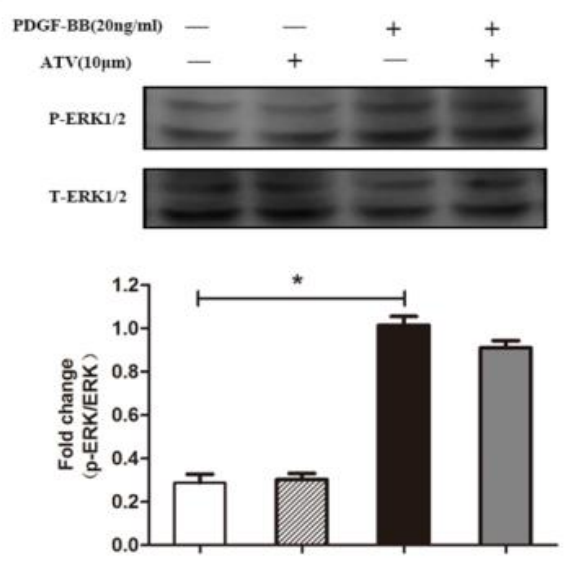

Fig. 6. Atorvastatin calcium inhibits the activation of PDGF-R $\beta$ signaling and Akt signaling pathways. VSMCs were pre-cultured in the presence or absence of ATV in serum-free medium for 30min, and then stimulated with $20 \mathrm{ng} / \mathrm{mL}$ PDGF- $\beta \beta$ for $5 \mathrm{~min}$ for the phosphorylation of PDGFR $\beta$, (PLC)- $\gamma 1$ and (ERK) $1 / 2$, or $15 \mathrm{~min}$ for Akt phosphorylation. Quantification of normalized densities for PDGFR $\beta$, (PLC)- $\gamma 1$, (ERK) 1/2 and Akt was shown. The graphs represent the relative activity of these kinases for three independent experiments. (A): PDGFR $\beta$ phosphorylation; (B): Akt phosphorylation; (C): (PLC)- $\gamma 1$ phosphorylation; (D): (ERK) $1 / 2$ phosphorylation. $* P<0.05$ compared with nonstimulated controls; $\# P<0.05$ compared with $20 \mathrm{ng} / \mathrm{mL}$ PDGF- $\beta \beta$-treated controls.

the activation of PDGF-R $\beta$ and its downstream signaling molecules, such as (PI3K)/Akt, (PLC)- $\gamma 1$ and (ERK) 1/2 (Fig. 6). Treatment with PDGF- $\beta \beta$ for 5 min markedly increased the phosphorylation of PDGFR $\beta$,(PLC)- $\gamma 1$ and (ERK) $1 / 2$ in VSMCs. Moreover, the phosphorylation of Akt was significantly increased after PDGF- $\beta \beta$ treatment for $15 \mathrm{~min}$ in VSMCs. In addition, atorvastatin calcium significantly inhibited PDGF- $\beta \beta$-treated PDGFR $\beta$ phosphorylation (Fig. 6A) and Akt phosphorylation (Fig. 6B) in VSMCs. However, atorvastatin calcium treatment had no significant effect on the PDGF- $\beta \beta$-treated phosphorylation of (PLC)- $\gamma 1$ (Fig. 6C) or (ERK) 1/2 (Fig. 6D) in VSMCs. These results indicated that atorvastatin calcium may inhibit cell proliferation through the PDGFR $\beta$ and Akt signaling pathways.

PDGFR $\beta$ inhibition attenuates the increased phosphorylation of Akt elicited by PDGF- $\beta \beta$ in VSMCS

Our data indicated that PDGF- $\beta \beta$ activated both the PDGFR $\beta$ and Akt signaling pathways. In addition, previous studies reported that there was cross-talk between the PDGFR $\beta$ and 


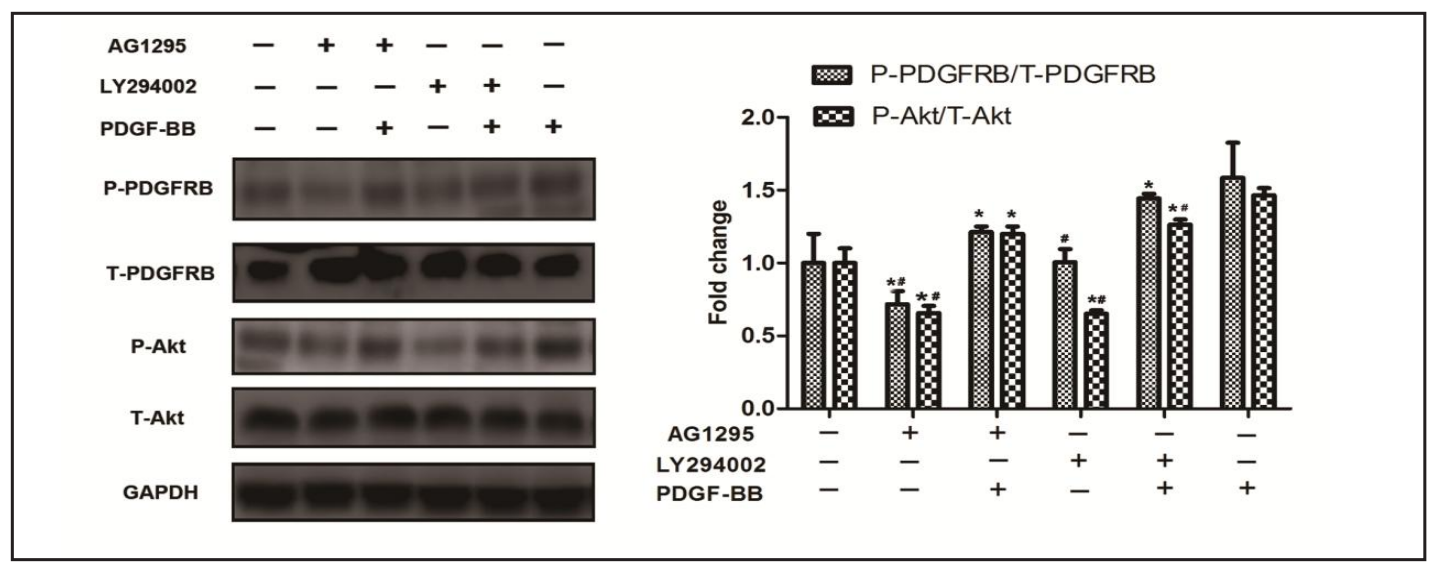

Fig. 7. PDGFR $\beta$ inhibition attenuates the increased phosphorylation of Akt elicited by PDGF- $\beta \beta$ in VSMCs. PDGFR $\beta$-specific inhibitor (AG1295) abolished phosphorylation of both PDGFR $\beta$ and Akt, whereas PI3K/ Akt inhibitor (LY294002) had no detectable effect on PDGFR $\beta$ phosphorylation. The results were presented as the means \pm SEM from 3 different experiments. $* P<0.05$ compared with nonstimulated controls; $\# P<$ 0.05 compared with $20 \mathrm{ng} / \mathrm{mL}$ PDGF- $\beta \beta$-treated controls.

Fig. 8. The effect of atorvastatin calcium on PDGF- $\beta \beta$-treated distribution of p-PDGFR $\beta$ and $p$ Akt in VSMCs. Immunofluorescence staining was performed to determine the expression and distribution of $\mathrm{p}$-PDGFR $\beta$ (A) and p-Akt (B), 400×. The expression of $\mathrm{p}$-PDGFR $\beta$ and $\mathrm{p}$ Akt were red, and nuclei were stained blue with DAPI. The micrographs shown in this Fig. are representative of three independent experiments with similar results.

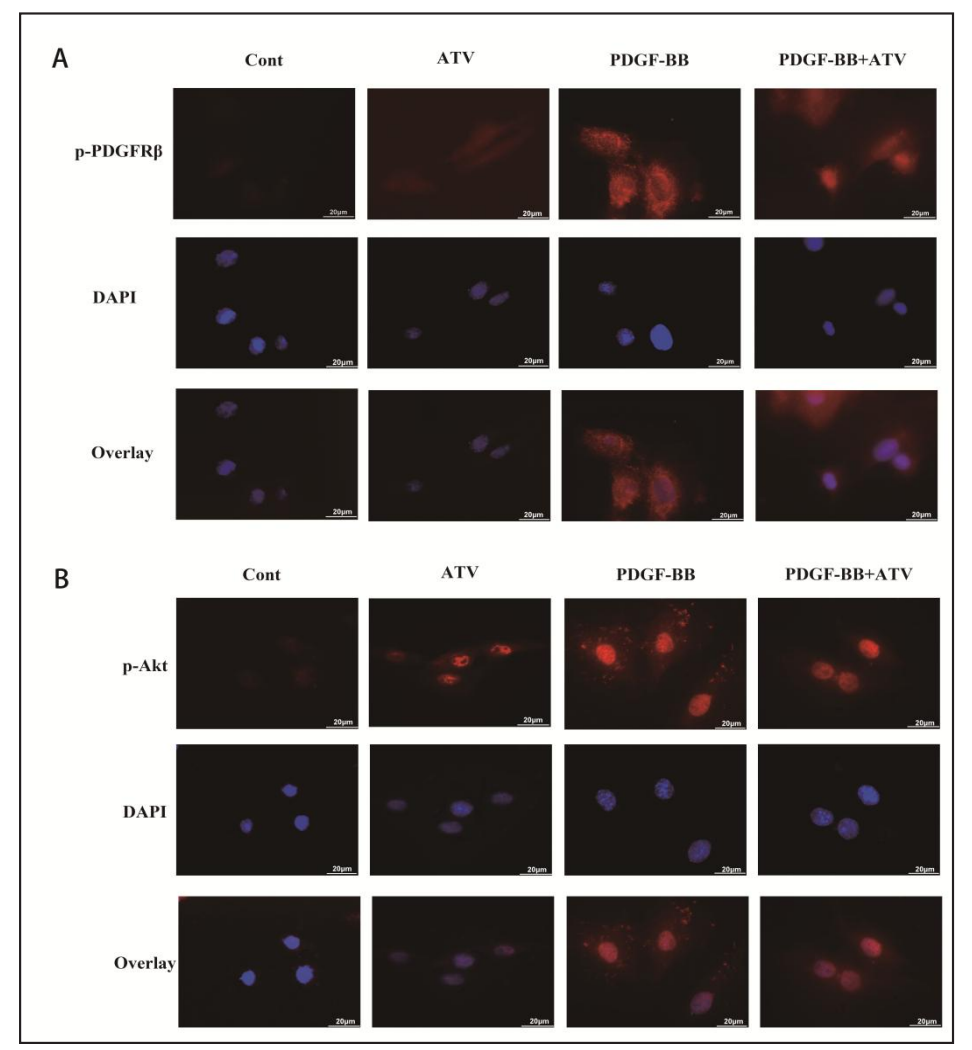

the (PI3K)/Akt pathways [13, 14]. Accordingly, AG1295 (a PDGFR $\beta$-specific inhibitor) and LY294002 (an inhibitor of PI3K) were used in our study. As shown in Fig. 7, the inhibitors effectively inhibited the phosphorylation of PDGFR $\beta$ and Akt, respectively. Furthermore, the PDGFR $\beta$-specific inhibitor (AG1295) not only abolished phosphorylation of PDGFR $\beta$ but also inhibited Akt activation. However, the PI3K/Akt inhibitor (LY294002) only decreased the phosphorylation of Akt; there was no detectable effect on PDGFR $\beta$ phosphorylation. These findings indicated that PDGFR $\beta$ likely served as an upstream regulator of Akt in PDGF- $\beta \beta$ treated VSMCs.

\section{KARGER}


A

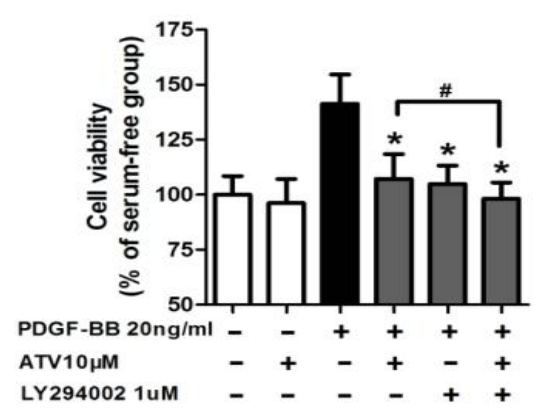

C

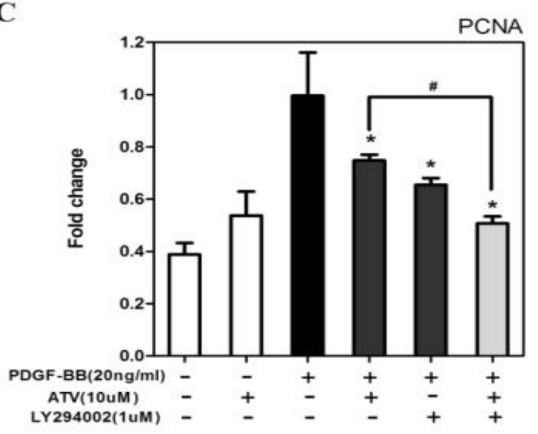

B

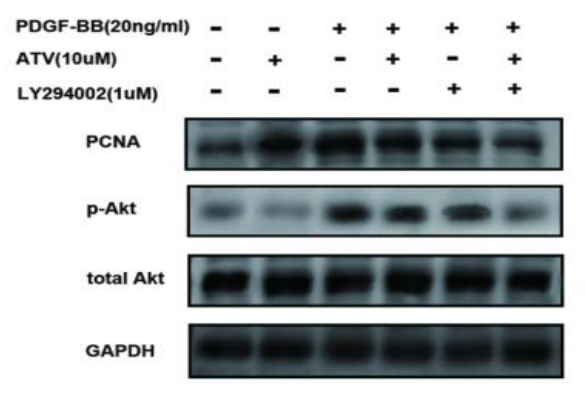

D

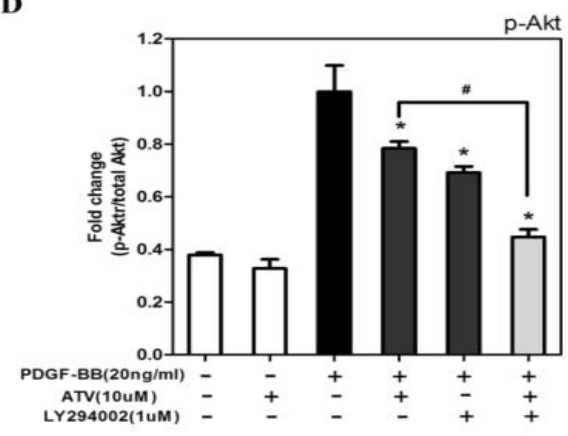

Fig. 9. Synergistic effects of atorvastatin calcium with Akt inhibitor on proliferation of VSMCs and expression of PCNA and p-Akt. (A) After 24h of starvation with serum-free DMEM, VSMCs were incubated in the presence or absence of the indicated concentration of atorvastatin calcium or LY294002 (Akt inhibitor, 1uM) with $20 \mathrm{ng} / \mathrm{mL}$ PDGF- $\beta \beta$ for $24 \mathrm{~h}$. VSMCs viability was evaluated by MTT assay. (B) VSMCs were pre-cultured in the presence or absence of ATV and LY294002 in serum-free medium for 30min, and then stimulated with 20ng/mL PDGF- $\beta \beta$ for $5 \mathrm{~min}$ (for Akt phosphorylation) or 24h (for PCNA expression). Quantification of normalized densities for p-Akt and PCNA was shown in C\&D. The graphs represent the relative activity of these kinases for three independent experiments. $\mathrm{P}<0.05$ compared with $20 \mathrm{ng} / \mathrm{mL}$ PDGF- $\beta \beta$-treated groups; $\# P<0.05$ compared with 20ng/mL PDGF- $\beta \beta+10$ u M ATV induced groups.

\section{The effect of atorvastatin calcium on PDGF- $\beta \beta$-treated distribution of $p-P D G F R \beta$ and $p$-Akt} in VSMCs

The above results revealed that atorvastatin calcium significantly inhibited PDGF- $\beta \beta$ treated PDGFR $\beta$ phosphorylation and Akt phosphorylation in VSMCs. Then, we evaluated whether the distribution of p-PDGFR $\beta$ and p-Akt expression was affected by atorvastatin calcium in PDGF- $\beta \beta$-treated VSMCs. As shown in Fig. 8A, compared with the control group, both the cytoplasmic and nuclear expression levels of p-PDGFR $\beta$ were significantly elevated in PDGF- $\beta \beta$-treated VSMCs, and p-PDGFR $\beta$ expression was stronger in the cytoplasm than in the nucleus. Moreover, pretreatment of atorvastatin calcium resulted in p-PDGFR $\beta$ translocation into the nucleus. As shown in Fig. 8B, the expression of p-Akt was barely detectable in the control or atorvastatin calcium alone groups. In the PDGF- $\beta \beta$-treated VSMCs, we found that strong fluorescent spots of p-Akt expression were gathered around the cell membranes. This result indicated that PDGF- $\beta \beta$-treated Akt activation started by p-Akt accumulation around cell membrane, thus the phosphorylation of Akt might be carried out on the cell membrane, and then activated p-Akt was translocated to the cytoplasm and nucleus. We also found that pretreatment with atorvastatin calcium decreased the expression of p-Akt in PDGF- $\beta \beta$ treated VSMCs, and fluorescent spots of p-Akt around the cell membrane disappeared (Fig. 8B).

\section{KARGER}




\section{Cellular Physiology \\ \begin{tabular}{ll|l} 
and Biochemistry & $\begin{array}{l}\text { DOI: } 10.1159 / 000484648 \\
\text { Published online: November 09, } 2017\end{array}$ & $\begin{array}{l}\text { (c) } 2017 \text { The Author(s). Published by S. Karger AG, Basel } \\
\text { www.karger.com/cpb }\end{array}$ \\
\hline
\end{tabular}}

Synergistic effects of atorvastatin calcium with Akt inhibitor on VSMCs proliferation

We determined whether the synergistic inhibition of VSMCs proliferation by atorvastatin calcium may occur with simultaneous treatment of Akt inhibitor. The expression of PCNA and Akt phosphorylation decreased in VSMCs treated with LY294002 (an Akt inhibitor) and atorvastatin calcium, compared to those of the compound alone-treated cells. These results indicated that the inhibitory effects of atorvastatin calcium on Akt phosphorylation were sufficient to suppress the PDGF-BB-stimulated proliferation of VSMCs (Fig. 9).

\section{Discussion}

In the present study, we investigated the anti-proliferative and anti-migratory activities of atorvastatin calcium on PDGF- $\beta \beta$-treated VSMCs and the related signal transduction pathways. Proliferation of VSMCs plays an essential role in a broad spectrum of cardiovascular disorders [3]. Neointimal thickening is mainly due to the abnormal proliferation and migration of VSMCs from the vascular media. Thus, inhibition of VSMC proliferation and migration represents a potentially important therapeutic strategy for the treatment of cardiovascular disorders [2]. Among many known growth factors, PDGF- $\beta \beta$ is one of the most important mitogens and chemoattractants for VSMCs and plays a central role in proliferative vascular diseases. Atorvastatin calcium is a selective HMG-CoA reductase inhibitor that has pleiotropic biological effects, which include inhibiting HMG-CoA reductase activity, increasing LDL receptor levels and inhibiting VLDL-C synthesis. Increasingly, evidence suggests that statins have effects beyond reducing cholesterol levels. In our previous study, we demonstrated that atorvastatin calcium inhibited the phenotypic modulation of PDGF- $\beta \beta$-treated VSMCs [26]. Furthermore, we conducted this study to investigate the related mechanisms under which atorvastatin calcium inhibited the abnormal proliferation and migration of PDGF- $\beta \beta$-treated VSMCs.

Our study indicated that the anti-proliferative effect of atorvastatin calcium was associated with cell cycle arrest in the G0/G1 phase. Cell cycle progression is tightly regulated through a complex network of regulatory molecules, including cyclins and CDKs. CDKs promote the G-to-S phase transition by phosphorylation of the $\mathrm{Rb}$ protein to form a gene product-PCNA [32]. Cyclin D, cyclin E, CDK2, and CDK4 are known as positive mediators during the progression from the G0/G1 to the $S$ phase of the cell cycle $[33,34]$. A previous study showed that regulation of the cell cycle could inhibit VSMCs proliferation [35]. Thus, the cell cycle arrest was considered an effective strategy for the inhibition of VSMCs proliferation. Our data indicated that atorvastatin calcium permitted VSMCs arrest in the G0/G1 phase and inhibited the expression of the cell cycle regulatory proteins PCNA, cyclin D1, CDK4, cyclin E and CDK2 in PDGF- $\beta \beta$-treated VSMCs compared to stimulation with PDGF- $\beta \beta$ alone. This result demonstrated that atorvastatin calcium inhibition of the PDGF$\beta \beta$-treated VSMC proliferation was due to the downregulation of the cycle regulatory protein expression, which resulted in the G0/G1 arrest.

During the process of pathogenic vascular disorders, dysfunctional VSMCs lead to abnormal migration activity [6]. Previous studies showed that MMPs, specifically MMP2 and MMP-9, were activated rapidly following vascular injury [36-38] and played an important role in disrupting the ECM in VSMCs [37, 39]. Degradation of the ECM promoted VSMC migration from the media of arterial walls to the intimal space, where VSMCs secreted more ECM products, progressively resulting in restenosis and neointima formation [40, 41]. Moreover, several migration regulatory proteins, including cell adhesion molecules ICAM1, VCAM-1 [27, 42], MMP2, and MMP-9 were reported to be vital regulators of abnormal VSMC migration [43-45]. In the present study, our results indicated that atorvastatin calcium inhibited the expression of ICAM-1, VCAM-1, MMP2, and MMP-9 induced by PDGF$\beta \beta$ stimulation. This demonstrated that atorvastatin calcium inhibited PDGF- $\beta \beta$-treated VSMC migration, at least partially owing to the suppression of the increased expression of migration regulatory proteins induced by PDGF- $\beta \beta$.

\section{KARGER}




\section{Cellular Physiology \begin{tabular}{ll|l} 
and Biochemistry & $\begin{array}{l}\text { DOI: 10.1159/000484648 } \\
\text { Published online: November 09, } 2017\end{array}$ & $\begin{array}{l}\text { (c) } 2017 \text { The Author(s). Published by S. Karger AG, Basel } \\
\text { www.karger.com/cpb }\end{array}$ \\
\hline
\end{tabular} \\ Chen et al.: ATV Inhibits VSMCs Proliferation and Migration Through PDGFRß-PI3K-Akt}

In this study, we showed that PDGF- $\beta \beta$ induced PDGF-R phosphorylation in VSMCs, and PDGF- $\beta \beta$ activity was altered by atorvastatin calcium. PDGF- $\beta \beta$ also activated many downstream signaling molecules, such as (PI3K)/Akt, (PLC)- $\gamma 1$ and (ERK)1/2 pathways, which are involved in cell growth and survival [46-48]. We found that phosphorylation of PDGFR $\beta$, Akt, (PLC)- $\gamma 1$ and (ERK) $1 / 2$ was induced by PDGF- $\beta \beta$; atorvastatin calcium inhibited PDGF- $\beta \beta$-treated phosphorylation of Akt but not (PLC)- $\gamma 1$ or (ERK) $1 / 2$. As we found that both the PDGFR $\beta$ and (PI3K)/Akt pathways were activated following stimulation by PDGF$\beta \beta$ and there was cross-talk between the PDGFR $\beta$ and (PI3K)/Akt pathways, we sought to determine whether Akt or PDGFR $\beta$ served as the upstream molecule in VSMCs stimulated by PDGF- $\beta \beta$. We observed that blocking the PDGFR $\beta$ pathway with a specific inhibitor abolished the phosphorylation of both PDGFR $\beta$ and Akt, whereas PDGFR $\beta$ phosphorylation was not affected following Akt inhibition in VSMCs. Our results indicated that PDGFR $\beta$ served as an upstream regulator of Akt in the setting of PDGF- $\beta \beta$ treatment in VSMCs.

\section{Conclusion}

The present study indicated that atorvastatin calcium inhibited abnormal proliferation and migration of VSMCs through G0/G1 cell cycle arrest and suppression of PDGFR $\beta$-PI3KAkt signaling cascade.

\section{Disclosure Statement}

The authors declare that there is no Disclosure Statement.

\section{Acknowledgements}

This study was supported by Key Laboratory of Myocardial Ischemia, Harbin Medical University, Chinese Ministry of Education to Dr. Shuang Chen (No.KF201509).

\section{References}

1 Ross R: Mechanisms of atherosclerosis--a review. Adv Nephrol Necker Hosp 1990;19:79-86.

2 Schwartz SM: Smooth muscle migration in atherosclerosis and restenosis. J Clin Invest 1997;100:S87-89.

- 3 Ross R: The pathogenesis of atherosclerosis: a perspective for the 1990s. Nature 1993;362:801-809.

4 Worth NF, Rolfe BE, Song J, Campbell GR: Vascular smooth muscle cell phenotypic modulation in culture is associated with reorganisation of contractile and cytoskeletal proteins. Cell Motil Cytoskeleton 2001;49:130-145.

5 Owens GK, Wise G: Regulation of differentiation/maturation in vascular smooth muscle cells by hormones and growth factors. Agents Actions Suppl 1997;48:3-24.

-6 Rzucidlo EM, Martin KA, Powell RJ: Regulation of vascular smooth muscle cell differentiation. J Vasc Surg 2007;45 A:A25-32.

7 Dzau VJ, Braun-Dullaeus RC, Sedding DG: Vascular proliferation and atherosclerosis: new perspectives and therapeutic strategies. Nat Med 2002;8:1249-1256.

8 Coats WD, Jr., Faxon DP: The role of the extracellular matrix in arterial remodelling. Semin Interv Cardiol 1997;2:167-176.

-9 Davies MG, Hagen PO: Pathobiology of intimal hyperplasia. Br J Surg 1994;81:1254-1269.

10 Sachinidis A, Locher R, Vetter W, Tatje D, Hoppe J: Different effects of platelet-derived growth factor isoforms on rat vascular smooth muscle cells. J Biol Chem 1990;265:10238-10243. 


\section{Cellular Physiology Cell Physiol Biochem 2017;44:215-228

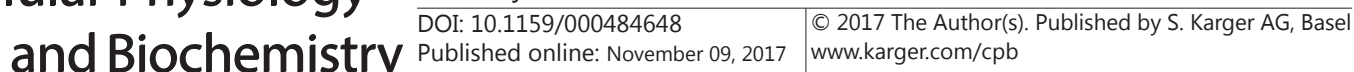 \\ Chen et al.: ATV Inhibits VSMCs Proliferation and Migration Through PDGFRß-PI3K-Akt}

11 Bornfeldt KE, Raines EW, Graves LM, Skinner MP, Krebs EG, Ross R: Platelet-derived growth factor. Distinct signal transduction pathways associated with migration versus proliferation. Ann N Y Acad Sci 1995;766:416-430.

12 Raines EW: PDGF and cardiovascular disease. Cytokine Growth Factor Rev 2004;15:237-254.

13 Andrae J, Gallini R, Betsholtz C: Role of platelet-derived growth factors in physiology and medicine. Genes Dev 2008;22:1276-1312.

-14 Farooqi AA, Waseem S, Riaz AM, Dilawar BA, Mukhtar S, Minhaj S, Waseem MS, Daniel S, Malik BA, Nawaz A, Bhatti S: PDGF: the nuts and bolts of signalling toolbox. Tumour Biol 2011;32:1057-1070.

-15 Heldin CH, Ostman A, Ronnstrand L: Signal transduction via platelet-derived growth factor receptors. Biochim Biophys Acta 1998;1378:F79-113.

-16 Goncharova EA, Ammit AJ, Irani C, Carroll RG, Eszterhas AJ, Panettieri RA, Krymskaya VP: PI3K is required for proliferation and migration of human pulmonary vascular smooth muscle cells. Am J Physiol Lung Cell Mol Physiol 2002;283:L354-363.

17 Muto A, Fitzgerald TN, Pimiento JM, Maloney SP, Teso D, Paszkowiak JJ, Westvik TS, Kudo FA, Nishibe T, Dardik A: Smooth muscle cell signal transduction: implications of vascular biology for vascular surgeons. J Vasc Surg 2007;45:A15-24.

18 Kim TJ, Lee JH, Lee JJ, Yu JY, Hwang BY, Ye SK, Shujuan L, Gao L, Pyo MY, Yun YP: Corynoxeine isolated from the hook of Uncaria rhynchophylla inhibits rat aortic vascular smooth muscle cell proliferation through the blocking of extracellular signal regulated kinase 1/2 phosphorylation. Biol Pharm Bull 2008;31:2073-2078.

19 Graf K, Xi XP, Yang D, Fleck E, Hsueh WA, Law RE: Mitogen-activated protein kinase activation is involved in platelet-derived growth factor-directed migration by vascular smooth muscle cells. Hypertension 1997;29:334-339.

20 Pyles JM, March KL, Franklin M, Mehdi K, Wilensky RL, Adam LP: Activation of MAP kinase in vivo follows balloon overstretch injury of porcine coronary and carotid arteries. Circ Res 1997;81:904-910.

-21 Corsini A, Bellosta S, Baetta R, Fumagalli R, Paoletti R, Bernini F: New insights into the pharmacodynamic and pharmacokinetic properties of statins. Pharmacol Ther 1999;84:413-428.

22 Inoue T, Node K: Statin therapy for vascular failure. Cardiovasc Drugs Ther 2007;21:281-295.

-23 Zuo Y, Wang Y, Hu H, Cui W: Atorvastatin Protects Myocardium Against Ischemia-Reperfusion Injury Through Inhibiting miR-199a-5p. Cell Physiol Biochem 2016;39:1021-1030.

24 Yue YH, Bai XD, Zhang HJ, Li YM, Hu L, Liu LY, Mao JP, Yang XY, Dila NM: Gene Polymorphisms Affect the Effectiveness of Atorvastatin in Treating Ischemic Stroke Patients. Cell Physiol Biochem 2016;39:630-638.

25 Porter KE, Naik J, Turner NA, Dickinson T, Thompson MM, London NJ: Simvastatin inhibits human saphenous vein neointima formation via inhibition of smooth muscle cell proliferation and migration. J Vasc Surg 2002;36:150-157.

26 Chen S, Liu B, Kong D, Li S, Li C, Wang H, Sun Y: Atorvastatin calcium inhibits phenotypic modulation of PDGF-BB-induced VSMCs via down-regulation the Akt signaling pathway. PLoS One 2015;10:e0122577.

27 Dong LH, Wen JK, Miao SB, Jia Z, Hu HJ, Sun RH, Wu Y, Han M: Baicalin inhibits PDGF-BB-stimulated vascular smooth muscle cell proliferation through suppressing PDGFRbeta-ERK signaling and increase in p27 accumulation and prevents injury-induced neointimal hyperplasia. Cell Res 2010;20:1252-1262.

-28 Newby AC: Matrix metalloproteinases regulate migration, proliferation, and death of vascular smooth muscle cells by degrading matrix and non-matrix substrates. Cardiovasc Res 2006;69:614-624.

29 Kim TJ, Han HJ, Lim Y, Song MC, Kim J, Hong JT, Yoo HS, Pyo MY, Hwang BY, Lee MK, Yun YP: Antiproliferative action of cudraflavone $\mathrm{B}$, isolated from Cudrania tricuspidata, through the downregulation of $\mathrm{pRb}$ phosphorylation in aortic smooth muscle cell proliferation signaling. J Cardiovasc Pharmacol 2009;53:341348.

-30 Kim TJ, Jeon J, Jin YR, Son DJ, Yoo HS, Hong JT, Ryu CK, Shin HS, Lee KH, Yun YP: Effects of KTJ740, a novel antithrombotic agent, on platelet-derived growth factor-induced rat aortic smooth muscle cell proliferation and cell cycle progression. J Cardiovasc Pharmacol 2007;49:280-286.

31 Seo JM, Kim TJ, Jin YR, Han HJ, Ryu CK, Sheen YY, Kim DW, Yun YP: YSK2821, a newly synthesized indoledione derivative, inhibits cell proliferation and cell cycle progression via the cell cycle-related proteins by regulating phosphatidylinositol-3 kinase cascade in vascular smooth muscle cells. Eur J Pharmacol 2008;586:74-81.

-32 Weinberg RA: The retinoblastoma protein and cell cycle control. Cell 1995;81:323-330. 


\section{Cellular Physiology Cell Physiol Biochem 2017;44:215-228 and Biochemistry \begin{tabular}{l|l} 
DOI: 10.1159/000484648 & O 2017 The Author(s). Published by S. Karger AG, Basel \\
wuww.karger.com/cpb
\end{tabular}

33 Braun-Dullaeus RC, Mann MJ, Sedding DG, Sherwood SW, von der Leyen HE, Dzau VJ: Cell cycle-dependent regulation of smooth muscle cell activation. Arterioscler Thromb Vasc Biol 2004;24:845-850.

34 Sherr CJ, Roberts JM: CDK inhibitors: positive and negative regulators of G1-phase progression. Genes Dev 1999;13:1501-1512.

-35 Gallo R, Padurean A, Jayaraman T, Marx S, Roque M, Adelman S, Chesebro J, Fallon J, Fuster V, Marks A, Badimon JJ: Inhibition of intimal thickening after balloon angioplasty in porcine coronary arteries by targeting regulators of the cell cycle. Circulation 1999;99:2164-2170.

-36 Sluijter JP, de Kleijn DP, Pasterkamp G: Vascular remodeling and protease inhibition--bench to bedside. Cardiovasc Res 2006;69:595-603.

37 Chase AJ, Newby AC: Regulation of matrix metalloproteinase (matrixin) genes in blood vessels: a multi-step recruitment model for pathological remodelling. J Vasc Res 2003;40:329-343.

38 Lu J, Hao J, Du H, Xiao B, Li Y, Yang X, Cui W: Amlodipine and Atorvastatin Improved Hypertensive Cardiac Remodeling through Regulation of MMPs/TIMPs in SHR Rats. Cell Physiol Biochem 2016;39:47-60.

39 Sasaguri Y, Murahashi N, Sugama K, Kato S, Hiraoka K, Satoh T, Isomoto H, Morimatsu M: Developmentrelated changes in matrix metalloproteinase expression in human aortic smooth muscle cells. Lab Invest 1994;71:261-269.

40 Glass CK, Witztum JL: Atherosclerosis. the road ahead. Cell 2001;104:503-516.

41 Newby AC, Zaltsman AB: Molecular mechanisms in intimal hyperplasia. J Pathol 2000;190:300-309.

-42 Koon CM, Woo KS, Leung PC, Fung KP: Salviae Miltiorrhizae Radix and Puerariae Lobatae Radix herbal formula mediates anti-atherosclerosis by modulating key atherogenic events both in vascular smooth muscle cells and endothelial cells. J Ethnopharmacol 2011;138:175-183.

43 Lee JJ, Zhang WY, Yi H, Kim Y, Kim IS, Shen GN, Song GY, Myung CS: Anti-proliferative actions of 2-decylamino-5, 8-dimethoxy-1, 4-naphthoquinone in vascular smooth muscle cells. Biochem Biophys Res Commun 2011;411:213-218.

-44 Karki R, Jeon ER, Kim DW: Nelumbo nucifera leaf extract inhibits neointimal hyperplasia through modulation of smooth muscle cell proliferation and migration. Nutrition 2013;29:268-275.

45 Cho A, Reidy MA: Matrix metalloproteinase-9 is necessary for the regulation of smooth muscle cell replication and migration after arterial injury. Circ Res 2002;91:845-851.

-46 Hommes DW, Peppelenbosch MP, van Deventer SJ: Mitogen activated protein (MAP) kinase signal transduction pathways and novel anti-inflammatory targets. Gut 2003;52:144-151.

47 Hughes AD, Clunn GF, Refson J, Demoliou-Mason C: Platelet-derived growth factor (PDGF): actions and mechanisms in vascular smooth muscle. Gen Pharmacol 1996;27:1079-1089.

48 Wang J, Chen H, Zhou Y, Su Q, Liu T, Wang XT, Li L: Atorvastatin Inhibits Myocardial Apoptosis in a Swine Model of Coronary Microembolization by Regulating PTEN/PI3K/Akt Signaling Pathway. Cell Physiol Biochem 2016;38:207-219. 